International Research Journal of Management, IT \& Social Sciences
Available online at https://sloap.org/journals/index.php/irjmis/
Vol. 7 No. 2, March 2020, pages: 30-37
ISSN: 2395-7492
https://doi.org/10.21744/irjmis.v7n2.859

\title{
Effect of Organizational Commitment, Job Stress and Work-Family Conflict to Turnover Intention
}

\author{
I Putu Kresna Saniscara Dewanta Putra ${ }^{a}$ \\ I Gusti Made Suwandana ${ }^{b}$
}

Article history:

Submitted: 09 November 2019

Revised: 18 December 2019

Accepted: 31 January 2020

\section{Keywords:}

employees;

organizational commitment;

turnover intention;

work stress;

work-family conflict;

\begin{abstract}
This research was conducted in several hotels in the Kuta Badung area, Bali. The number of samples taken was 105 married female employees, using the nonprobability sampling method, specifically purposive sampling. Data collection is done through observation, interviews, and questionnaires. The analysis technique used is multiple linear regression. Based on the results of the analysis found that (1) organizational commitment has a negative and significant effect on turnover intention, so the higher organizational commitment is felt by employees, the lower the desire to leave the company, and vice versa, the lower the organizational commitment felt by employees, the higher the desire to leave the company. (2) work stress has a positive and significant effect on turnover intention, so the higher the level of work stress felt by employees, the greater the intention of employees to leave the organization. (3) work-family conflict has a positive and significant effect on turnover intention, so the higher the conflict a person feels, the higher the person's desire to leave the company.
\end{abstract}

International research journal of management, IT and social sciences $@ 2020$.

This is an open access article under the CC BY-NC-ND license (https://creativecommons.org/licenses/by-nc-nd/4.0/).

\section{Corresponding author:}

I Putu Kresna Saniscara Dewanta Putra,

Faculty of Economics and Business, Udayana University, Denpasar, Indonesia.

Email address: kresna.saniscara@gmail.com

Udayana University, Denpasar, Indonesia

Udayana University, Denpasar, Indonesia 


\section{Introduction}

Based on observations and interviews conducted by researchers with the Human Resources Department at a number of hotels in the Kuta Badung area, Bali, it was found that the factors that often cause employees to leave the company are a decrease in organizational commitment as indicated by symptoms that look like decreased employee enthusiasm in carrying out their work, the lack of cooperation that exists between employees, as well as the low initiative of employees which indicates that the level of employee discipline is decreasing. Employees also often complain about excessive workloads that can cause employees to feel stressed in doing their jobs and can make employees think of leaving the company. In addition, the demands of responsibilities within the family also often make employees want to leave the company because of differences in interests between work and family which causes employees to hold dual roles in work and family.

Regarding the factors that affect turnover intention in some Kuta Badung, Bali, Adi \& Ratnasari (2015) hotels, it also revealed that one of the factors affecting turnover intention is an organizational commitment, where organizational commitment contributes to predicting the output variables of an organization such as intention out. Srimulyani (2009), states that organizational commitment is a psychological condition that characterizes employee relations with the organization and has implications for the employee's decision to continue or quit the membership of the organization. Robbins and Timothy (in Zelvia, 2015), defines an organizational commitment to the extent that a person sides with an organization and its goals and desires to maintain membership in the organization.

Khan et al. (2014), shows that high organizational commitment will result in decreased employee turnover intention. Choong in Khan et al. (2014), said employees with high organizational commitment would certainly be happy to be in the organization. One form of commitment shown by employees is increased performance, low absenteeism and a desire not to look for other work alternatives. If organizational commitment is low, employee loyalty to the company will also be low and increase the desire of employees not to maintain membership in the company (Novriyadhi \& Riana, 2015).

Based on observations and interviews conducted by researchers of married female employees in a number of hotels in the Kuta area regarding employee commitment to the company, there are several problems that make employees experience organizational commitment, one of which is a job description that is not in accordance with the contents of the contract that causes excitement and employee morale in carrying out their work decreases. In addition, the low commitment of employees is also caused by the provision of compensation that is often late so that the impact on employee commitment to the organization.

In addition to organizational commitment, factors that can affect turnover intention are work stress (Siddiqui \& Raja, 2015). Stress is a major cause of employee turnover intention (Mitchell et al., 2000). The more life needs that must be met, the increasingly heavy workload, and increasingly fierce work competition can lead to work stress that ultimately triggers employee turnover intention (Syahronica, 2015). Stress is a person's response to something that he faces both in terms of interactions with others as well as to work, the environment, and events that require attention that can bring positive or negative impact on someone (Anatan \& Ellitan, 2007). Rivai \& Sagala (2005), work stress is a condition of tension that creates a physical and psychological imbalance, which affects emotions, thought processes, and the condition of an employee.

Sohail \& Rehman (2015), work stress is defined as an adverse physical and mental reaction and arises when work demands are not in accordance with the abilities, skills or requirements of staff. Altangerel et al. (2015), work stress is a problem faced with organizations that often have undesirable effects on staff and organizational performance. Jamadin et al. (2015), defines work stress as the inability to cope with the stresses experienced in his work. Stress that cannot be handled properly usually results in the inability of people to interact positively with their environment, both outside and inside (Budiyono \& Haryati, 2016). Nazenin \& Palupiningdyah (2014), stated that work stress has a positive effect on turnover intention.

Based on observations and interviews conducted by researchers of married female employees in a number of hotels in the Kuta area regarding employee work stress, work stress is indicated to occur and can be seen from the high workload that will cause employees to feel stressed in carrying out their work. For example, some butler division employees experience work stress due to mobile duty which must always handle several divisions within the hotel so that they have a high workload and responsibility, especially at hotel check-in hours, usually many guests arrive at the same time, so hotel conditions become crowded which causes employees to become stressed and overwhelmed in carrying out their work. The level of stress experienced by employees varies depending on each level (position) in accordance with the workload received. Pressure from superiors or clients also adds to the workload of employees

Putra, I. P. K. S. D., \& Suwandana, I. G. M. (2020). Effect of organizational commitment, job stress and work-family conflict to turnover intention. International Research Journal of Management, IT and Social Sciences, 7(2), 30-37. https://doi.org/10.21744/irjmis.v7n2.859 
such as tasks or work that has not been completed, must be completed on the same day so that employees must work beyond working hours that should be.

Another factor that can affect turnover intention besides organizational commitment and work stress is work-family conflict (WFC). Scmidt and Kochan in Rifandi (2017), states that conflict is a dispute or struggle between two parties which is marked by openly showing hostility, and or deliberately interfering with the achievement of the objectives of the opposing party. Malik \& Awan (2015), explained that work-family conflict is a form of conflict in which the role pressure associated with membership in one organization is contrary to the pressure that comes from membership in the family. This conflict occurs if someone experiences stress in doing their work.

Gahyyur and Jamal (in Paramita \& Subudi, 2017), Work-family conflict is a demand for two-way roles where work demands interfere with family demands or responsibilities such as family care responsibilities interfered with workrelated responsibilities that create some undesirable outcomes such as stress, poor health, work-related conflicts, absence, and turnover. Bakker et al. (2014), stated that work-family conflict as a disturbance in the work environment to the lives of employees when individuals choose to work it will cause obstacles to fulfill family obligations. Winefield et al. (2014), suggested that work-family conflicts include substances that explain various physical symptoms and psychological distress after taking into account work demands and controls and reducing work performance. Workfamily conflict can be caused due to the lack of tolerance of working hours for employees who are married, more overtime and are constrained in asking permission from the company for the benefit of the employee's own family (Nanda \& Utama, 2015).

Based on observations and interviews conducted by researchers of several married female employees in a number of hotels in the Kuta area, this work-family conflict can be seen especially indeed for female employees who are married and have children, because they are bumped into busy working hours and deadlines for work to be done. Some employees suddenly have to replace other employees or even have to work double shifts because there are employees who are unable to attend due to one reason or another. Employees in several hotels in the Kuta area are also mostly Hindu, so many traditional ceremonies, as well as one of the roles of individuals in the family and on the other hand, must follow the rules in the hotel that are not easy to get work permits and allowances because they have to be present and get home from work on time according to the hours of work.

Based on the problems found in some hotels in Kuta Badung, Bali and the results of research conducted by several previous researchers, this study will retest some factors that are predicted to influence turnover intention. These factors are organizational commitment, work stress, and work-family conflict, so researchers raised the title "The Effect of Organizational Commitment, Work Stress, and Work-Family Conflict Against Turnover Intention (Study of married female employees in several hotels in Kuta Badung, Bali) ". The final goal of this research is to provide solutions and suggestions that companies can take to reduce the level of employee turnover intention from the perspective of organizational commitment, work stress, and work-family conflict.

\section{Literature review and hypothesis development}

Several studies have proven that organizational commitment influences employee turnover intention. Research by Widyantara \& Ardana (2015), found that organizational commitment had a negative and significant effect on turnover intention. The research results of Rarasanti \& Suana (2016), are also supported by research by Susila Putra \& Surya (2016), suggesting that organizational commitment has a negative influence on turnover intention. The same result was found by Anisah (2016), where organizational commitment variable had a negative and significant effect on turnover intention. According to research conducted by Hasbie et al. (2016), revealed that organizational commitment negatively affected employee turnover intention. So the higher organizational commitment felt by employees, the lower the desire to leave the company, and vice versa, the lower the organizational commitment felt by employees, the higher the desire to leave the company. Based on previous research, the following hypotheses can be formulated:

H1: Organizational commitment has a negative and significant effect on Turnover Intention.

Several studies have proven that work stress affects employee turnover intention (Christy \& Priartini, 2019; Yunita \& Saputra, 2019). The results of the study by Suciati \& Minarsih (2015), show that work stress has a positive effect on turnover intention. The results of Pande Saeka (2016), also suggested that work stress has a positive effect on turnover intention. In a study by Mamewe (2016), the results of work stress affect the intention to leave employees, the higher the level of work stress felt by employees, the greater the intention of employees to leave the organization. Research Parvaiz et al. (2015), shows work stress has a positive and significant relationship with turnover intention, if employees experience work stress and do not have a suitable mechanism to deal with work stress, it will lead to the desire of 
employees to leave. Siddiqui \& Raja (2015), in their research, showed that work stress has a positive and significant effect on turnover intention because excessive pressure and nervous tension make employees think of leaving the organization. Based on previous research, the following hypotheses can be formulated:

H2: Job Stress has a positive and significant effect on Turnover Intention.

Several studies have proven that work-family conflicts affect employee turnover intention (Kusumanegara et al., 2018). Nohe \& Sonntag (2014), obtained the result that work-family conflict is an important and positive significant effect that must be considered by organizations to reduce the level of turnover intention. Nanda \& Utama (2015), also got research results where work-family conflict had a significant positive effect on the level of turnover intention. Wulandari \& Adyani (2016) in their research said that work-family conflict has a positive effect on turnover intention. The same research result was also stated by Zahroh \& Gde (2016), which resulted that work-family conflict had a positive effect on turnover intention. Research conducted by Ngadiman et al. (2014), also suggested that work-family conflict had a positive effect on turnover intention. The higher the perceived conflict, the higher one's desire to leave the company. Based on previous research, the following hypotheses can be formulated:

H3: Work-Family Conflict has a positive and significant effect on Turnover Intention.

\section{Materials and Methods}

This research was conducted at several hotels in Kuta Badung, Bali. This location was chosen because there are problems related to turnover intention. The population of this study was all female employees with married status in some Kuta Badung, Bali hotels, amounting to 105 respondents. Multiple linear regression analysis was used to address the problems in this study. Problems that must be answered in this study are independent variables (organizational commitment, work stress, work-family conflict) to the dependent variable (turnover intention). Based on the conceptual framework and research hypothesis.

\section{Results and Discussions}

This analysis technique is used to find out how much influence the independent variables are: Organizational Commitment (X1), Work Stress (X2), Work-Family Conflict (X3), on the dependent variable, Turnover Intention (Y).

Multiple Linear Regression Analysis

Table 1

Results of multiple linear regression analysis

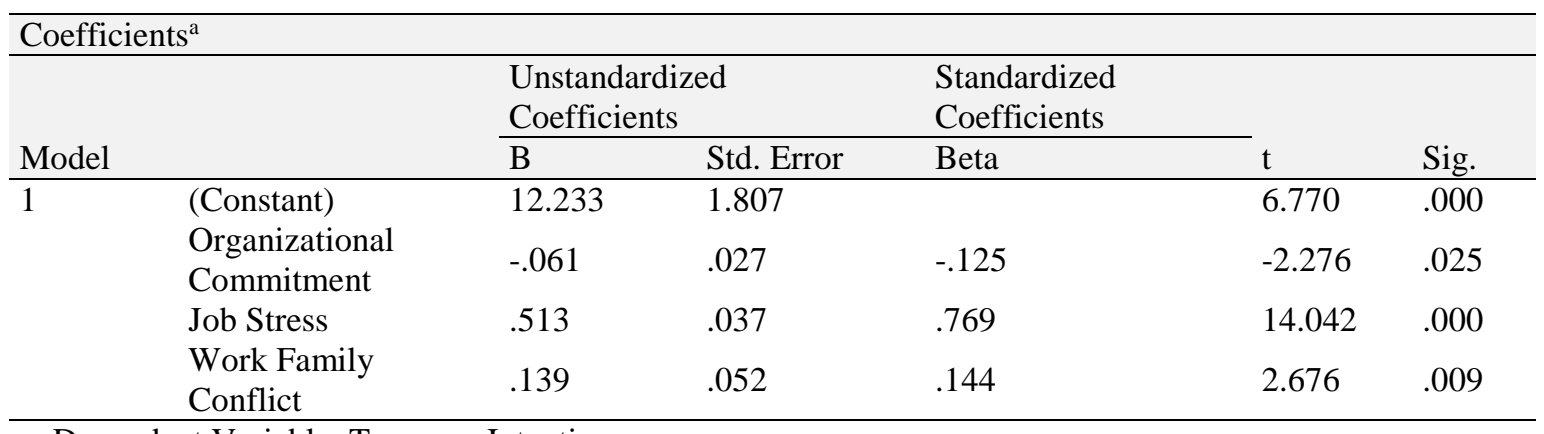

a. Dependent Variable: Turnover Intention

Primary Data, 2019

\section{Effect of organizational commitment on turnover intention}

Based on the t-test results the effect of organizational commitment on turnover intention obtained a significance value of 0.025 with a regression coefficient of 0.061 negative value. The significance value of $0.025<0.05$ indicates that $\mathrm{H} 1$

Putra, I. P. K. S. D., \& Suwandana, I. G. M. (2020). Effect of organizational commitment, job stress and work-family conflict to turnover intention. International Research Journal of Management, IT and Social Sciences, 7(2), $30-37$. https://doi.org/10.21744/irjmis.v7n2.859 
was accepted. This result means that organizational commitment is thought to be significantly negatively related to turnover intention. This means that if an organizational commitment is getting better, then the turnover intention is getting worse, on the contrary, if an organizational commitment is getting worse, the turnover intention will get better too.

Several studies have proven that organizational commitment influences employee turnover intention. Research by Widyantara \& Ardana (2015), found that organizational commitment had a negative and significant effect on turnover intention. The research results of Rarasanti \& Suana (2016), are also supported by research by Putra \& Surya (2016) suggesting that organizational commitment has a negative influence on turnover intention. The same result was found by Anisah (2016), where organizational commitment variable had a negative and significant effect on turnover intention. According to research conducted by Hasbie et al. (2016), revealed that organizational commitment negatively affected employee turnover intention. So the higher organizational commitment felt by employees, the lower the desire to leave the company, and vice versa, the lower the organizational commitment felt by employees, the higher the desire to leave the company.

\section{Effects of job stress on turnover intention}

Based on the results of the t-test the effect of work stress on turnover intention obtained a significance value of 0,000 with a regression coefficient of 0.513 positive. The significance value of $0,000<0.05$ indicates that $\mathrm{H} 1$ was accepted. These results mean that work stress is thought to be significantly related to turnover intention. This means that if work stress is getting better, then the turnover intention is getting better, conversely, if work stress is getting worse then the turnover intention will get worse too.

Several studies have proven that work stress affects employee turnover intention. The results of the study by Suciati \& Minarsih (2015), show that work stress has a positive effect on turnover intention. The results of the study by Pande Saeka (2016) also suggest that work stress has a positive effect on turnover intention. In a study by Mamewe (2016), the results of work stress affect the intention to leave employees, the higher the level of work stress felt by employees, the greater the intention of employees to leave the organization. Research by Parvaiz et al. (2015), shows that work stress has a positive and significant relationship with turnover intention, if the employee experiences work stress and do not have a suitable mechanism to deal with the work stress, it will cause the employee's desire to leave. Siddiqui \& Raja (2015) in their research showed that work stress has a positive and significant effect on turnover intention because excessive pressure and nervous tension make employees think of leaving the organization.

\section{Effects of work-family conflict on turnover intention}

Based on the results of the t-test the effect of work-family conflict on turnover intention obtained a significance value of 0.009 with a regression coefficient of 0.139 positive. The significance value of $0.009<0.05$ indicates that $\mathrm{H} 1$ was accepted. This result means that work-family conflict is thought to be significantly related to turnover intention. This means that if the work-family conflict gets better, the turnover intention gets better, on the contrary, if the work-family conflict gets worse the turnover intention will get worse too.

Several studies have proven that work-family conflicts affect employee turnover intention. Nohe \& Sonntag (2014) obtained the result that work-family conflict is an important and positive significant effect that must be considered by organizations to reduce the level of turnover intention. Nanda \& Utama (2015), also got research results where workfamily conflict had a significant positive effect on the level of turnover intention. Wulandari \& Adyani (2016), in their research, said that work-family conflict has a positive effect on turnover intention. The same research result was also stated by Zahroh \& Gde (2016), which resulted that work-family conflict had a positive effect on turnover intention. Research conducted by Ngadiman et al. (2014), also suggested that work-family conflict had a positive effect on turnover intention. The higher the perceived conflict, the higher one's desire to leave the company.

\section{Coefficient of determination $\left(R^{2}\right)$}

The coefficient of determination $\left(\mathrm{R}^{2}\right)$ is used to measure the contribution of independent variables (organizational commitment, work stress, and work-family conflict) to the dependent variable (turnover intention). Testing the coefficient of determination in this study will use the help of the SPSS program. 
Table 2

Coefficient of determination $\left(\mathrm{R}^{2}\right)$

\begin{tabular}{lllll}
\hline & \multicolumn{3}{c}{ Model Summary $^{\mathrm{b}}$} \\
\hline Model & $\mathrm{R}$ & R Square & Adjusted R Square & Std. Error of the Estimate \\
\hline 1 & $.825^{\mathrm{a}}$ & .681 & .673 & 2.001 \\
\hline
\end{tabular}

Primary Data, 2019

Based on table 2 it can be observed that the adjusted R2 value of 0.673 means that $67.3 \%$ change (up and down) in turnover intention is influenced by (organizational commitment, work stress, and work-family conflict, while the remaining $47.8 \%$ is influenced by factors other than this research.

\section{Conclusion}

Based on the presentation it can be stated that organizational commitment significantly negatively influences turnover intention. These results imply that in order to decrease turnover intention, the company management should increase organizational commitment in accordance with the workload and the benefits of the company. In addition, management should provide appropriate incentives so that turnover intention will decrease.

Job stress has a significant positive effect on turnover intention. This implies that to increase turnover intention the company management should reduce working hours in accordance with applicable regulations in accordance with labor laws. In addition, the management of the company should not give responsibilities that are not in accordance with the position and job description carried by the employee. In addition, the work-family conflict has a significant positive effect on turnover intention. These results imply that management should condition the work-family conflict so that it does not occur. This can be done by designing a supportive work environment and implementing policies so that employees can provide support to one another.

\section{Conflict of interest statement}

The authors declared that they have no competing interests.

Statement of authorship

The authors have a responsibility for the conception and design of the study. The authors have approved the final article.

\section{Acknowledgments}

We are grateful to two anonymous reviewers for their valuable comments on the earlier version of this paper.

Putra, I. P. K. S. D., \& Suwandana, I. G. M. (2020). Effect of organizational commitment, job stress and work-family conflict to turnover intention. International Research Journal of Management, IT and Social Sciences, 7(2), $30-37$. https://doi.org/10.21744/irjmis.v7n2.859 


\section{References}

Adi, A. Z., \& Ratnasari, S. L. (2015). Pengaruh Komitmen Organisasi, Penghargaan dan Kepuasan Kerja Terhadap Perputaran Karyawan Pada Perbankan Syariah di Kota BATAM. Etikonomi, 14(1), 194843.

Altangerel, O., Ruimei, W., Elahi, E., \& Dash, B. (2015). Investigating the effect of job stress on performance of employees. International Journal of Scientific and Technology Journal, 4(2), 276-280.

Anatan, L., \& Ellitan, L. (2007). Manajemen Sumber Daya Manusia dalam Bisnis Modern. Bandung: Alfabeta.

Anisah, H. U. (2016). Pengaruh Kepuasan Kerja dan Komitmen Organisasi Terhadap Turnover Intention Karyawan (Studi Pada Bank Perkreditan Mitratama Arthabuana). JWM (Jurnal Wawasan Manajemen), 3(3), 191-204.

Bakker, A., Akihito S., Kyokok S., \& Norito K. (2014). Work Engagement Versus Woekaholism: A Test of The spillovercrossover Model. Journal of Managerial Psychology, 4(1) : 63-80

Budiyono, R., \& Haryati, T. (2016). Analisa Pengaruh Kepuasan Kerja, Stress Kerja, dan Komitmen Organisasi Terhadap Turnover Intention (Studi Pada PT. Duta Service Semarang). Jurnal STIE Semarang, 8(1), 36-52.

Christy, M. Y. P., \& Priartini, P. S. (2019). Role of work stress and organizational commitments in educating workload effect on intention to quit. International Research Journal of Management, IT and Social Sciences, 6(4), 8-16. https://doi.org/10.21744/irjmis.v6n4.632

Hasbie, S. P., Faslah, R., \& Swaramarinda, D. R. (2016). Kepuasan Kerja, Komitmen Organisasi dan Keinginan Berpindah: Studi Pada Karyawan Pahala Express Jatiasih Bekasi. Jurnal Pendidikan Ekonomi Dan Bisnis (JPEB), 4(1), 79-86.

Jamadin, N., Mohamad, S., Syarkawi, Z., \& Noordin, F. (2015). Work-family conflict and stress: Evidence from Malaysia. Journal of Economics, Business and Management, 3(2), 309-312.

Khan, M. S., Kundi, G. M., Khan, S., Khan, I., Khan, H., \& Yar, N. B. (2014). The Cause-\& Effect and Correlation between Job Satisfaction and Organizational commitment on Intention to leave among the Academicians in higher Educational Institutions of Khyber Pakhtunkhwa, Pakistan. International Journal of Academic Research in Business and Social Sciences, 4(2), 100. https://doi.org/10.6007/IJARBSS/v4-i2/609

Khan, M. S., Kundi, G. M., Khan, S., Khan, I., Khan, H., \& Yar, N. B. (2014). The Cause-\& Effect and Correlation between Job Satisfaction and Organizational commitment on Intention to leave among the Academicians in higher Educational Institutions of Khyber Pakhtunkhwa, Pakistan. International Journal of Academic Research in Business and Social Sciences, 4(2), 100. https://doi.org/10.6007/IJARBSS/v4-i2/609

Kusumanegara, I. S., Asmony, T., \& Numayanti, S. (2018). Work-family conflict on turnover intention regarding work stress as intervening variable. International Journal of Social Sciences and Humanities, 2(2), 141-154. https://doi.org/10.29332/ijssh.v2n2.153

Malik, M. S., \& Awan, A. G. (2015). Role of work family conflict on organizational commitment and organizational effectiveness. Nigerian Chapter of Arabian Journal of Business and Management Review, 62(1891), 1-12.

Mamewe, L. (2016). Stres Kerja Dan Iklim Organisasi Serta Pengaruhnya Terhadap Turn Over Intention Dengan Kepuasan Kerja Sebagai Variabel Pemediasi. Jurnal Riset Bisnis dan Manajemen, 3(4).

Mitchell, O., Mackenzie, D. L., Styve, G. J., \& Gover, A. R. (2000). The impact of individual, organizational, and environmental attributes on voluntary turnover among juvenile correctional staff members. Justice Quarterly, 17(2), 333-357. https://doi.org/10.1080/07418820000096351

Nanda, N. L. N. K., \& Utama, I. W. M. (2015). Pengaruh Konflik Kerja-Keluarga dan Kepuasan Kerja Terhadap Tingkat Turnover Intention Karyawan pada Restoran Pizza Hut Mall Bali Galeria. E-Jurnal Manajemen, 4(9).

Nazenin, S., \& Palupiningdyah, P. (2014). Peran Stres Kerja Dan Kepuasan Kerja Untuk Mengurangi Turnover Intention. Jurnal Dinamika Manajemen, 5(2).

Ngadiman, N., Muchlish, M., \& Bangun, N. (2014). Prinsip pengendalian, ambiguitas peran, konflik peran, dan kinerja karyawan serta keinginan berpindah kerja (studi empiris pada profesi dosen di dki jakarta). Konferensi Ilmiah Akuntansi I.

Nohe, C., \& Sonntag, K. (2014). Work-family conflict, social support, and turnover intentions: A longitudinal study. Journal of Vocational Behavior, 85(1), 1-12. https://doi.org/10.1016/j.jvb.2014.03.007

Novriyadhi, R. O., \& Riana, I. G. (2015). Pengaruh Keadilan Organisasional Terhadap Kepuasan Kerja Dan Komitmen Organisasi Pada PT Astra International Auto 2000 Denpasar. E-Jurnal Manajemen, 4(6).

Paramita, I. G. A. M., \& Subudi, M. (2017). Pengaruh Konflik Pekerjaan-keluarga terhadap Turnover Intention melalui Mediasi Kepuasan Kerja pada Hoki Bank Cabang Gatot Subroto. E-Jurnal Manajemen, 6(12), 6441-6470.

Parvaiz, L., Batool, S., Khalid, A., \& AftabFarooqi, Y. (2015). Impact of Stressors (Role conflict, Role overload, Leadership Support and Organizational Politics) on Job Stress and its subsequent impact on Turnover Intention. International Journal of Business and Management Invention, 4(10), 52-63. 
Putra, D. K., \& Surya, I. B. K. (2016). Pengaruh Kepuasan Gaji terhadap Turnover Intention dengan Komitmen Organisasional sebagai Mediasi pada Rumah Sakit Umum Premagana. E-Jurnal Manajemen, 5(7).

Rarasanti, I. A. P., \& Suana, I. W. (2016). Pengaruh job embeddedness, kepuasan kerja, dan Komitmen organisasional terhadap turnover intention Karyawan. E-Jurnal Manajemen, 5(7).

Rifandi. (2017). Pengaruh Konflik Terhadap Kinerja Pegawai Pada Dinas Pekerjaan Umum Provinsi Sulawesi Tenggara. Fakultas Ekonomi dan Bisnis Universitas Halu Oleo Kendari. Skripsi. 8(9). 246-257.

Rivai, V., \& Sagala, E. J. (2005). Manajemen sumber daya manusia. Jakarta: Raja Grafindo Persada.

Saeka, I. P. A. P., \& Suana, I. W. (2016). Pengaruh Kepuasan Kerja, Komitmen Organisasional dan Stres Kerja terhadap Turnover Intention Karyawan PT. Indonusa Algaemas Prima Bali. E-Jurnal Manajemen, 5(6).

Siddiqui, A. A., \& Jamil, R. A. (2015). Antecedents of Employees' Turnover Intentions: Evidence from Private Educational Institutions. American Journal of Economics and Business Administration, 7(4), 160.

Snir, R., Harpaz, I., Bakker, A. B., Shimazu, A., Demerouti, E., Shimada, K., \& Kawakami, N. (2014). Work engagement versus workaholism: A test of the spillover-crossover model. Journal of Managerial Psychology.

Sohail, M., \& Rehman, C. A. (2015). Stress and Health at the Workplace-A Review of the Literature. Journal of Business Studies Quarterly, 6(3), 94.

Srimulyani, V. A. (2009). Tipologi dan Anteseden Komitmen Organisasi. Jurnal Ilmiah Widya Warta, 33(1), 41-52.

Suciati, A. T. H., \& Minarsih, M. M. (2015). Job insecurity and job stress effect of turnover intention on PT. Berkat Abadi Surya Cemerlang Semarang (HO). Journal of Management, 1(1).

Syahronica, G. (2015). Pengaruh kepuasan kerja dan stres kerja terhadap turnover intention (Studi pada karyawan departemen dunia fantasi PT Pembangunan Jaya Ancol, Tbk). Jurnal administrasi bisnis, 20(1).

Wibowo, Putro. 2014. Pengaruh Stres Kerja Terhadap Kepuasan Kerja Dan Komitmen Organisasional Karyawan UD. Ulam Sari Denpasar. Jurnal Manajemen PPS Unud. 4(2): 125-145.

Widyantara, I. B. P., \& Ardana, I. K. (2015). Pengaruh kepuasan kerja dan komitmen organisasi terhadap intensitas turnover karyawan. E-Jurnal Manajemen, 4(6).

Winefield, H. R., Boyd, C., \& Winefield, A. H. (2014). Work-family conflict and well-being in university employees. The Journal of psychology, 148(6), 683-697. https://doi.org/10.1080/00223980.2013.822343

Wulandari, I. A. D., \& Adnyani, I. G. A. D. (2016). Pengaruh Work Family Conflict Terhadap Turnover Intention Melalui Mediasi Kepuasan Kerja Pada Hotel Grand Inna Kuta. E-Jurnal Manajemen, 5(10).

Yunita, P. I., \& Saputra, I. G. N. W. H. (2019). Millennial generation in accepting mutations: Impact on work stress and employee performance. International Journal of Social Sciences and Humanities, 3(1), 102-114. https://doi.org/10.29332/ijssh.v3n1.268

Zahroh, R., \& Sudibya, G. A. (2016). Pengaruh Komitmen Organisasi dan Konflik Kerja-Keluarga Terhadap Intention To Quit Karyawan Pada Restoran Kudeta di Seminyak Kuta. E-Jurnal Manajemen, 5(1).

Zelvia, D. (2015). Pengaruh Budaya Organisasi, Kepemimpinan dan Kepuasan Kerja Terhadap Komitmen Organisasi dan Kinerja Karyawan PT. Telkom Medan.

Putra, I. P. K. S. D., \& Suwandana, I. G. M. (2020). Effect of organizational commitment, job stress and work-family conflict to turnover intention. International Research Journal of Management, IT and Social Sciences, 7(2), $30-37$. https://doi.org/10.21744/irjmis.v7n2.859 